\title{
The Mercosur Experience and Theories of Regional Integration
}

\section{Carlos Ricardo Caichiolo*}

\begin{abstract}
This article examines the degree to which Mercosur conforms with theories of regional integration, taking into consideration its institutionalisation, its particular characteristics, the characteristics of its member states, and its impact on policy arrangements among those member states. It also compares Mercosur to the European Union. I conclude that theories of integration fail to provide a full explanation of the process of regional integration in Mercosur.
\end{abstract}

Keywords: Mercosur; Theories of Integration; Neofunctionalism; Liberal Intergovernmentalism; Civil Society; Economic Interdependence.

\section{Introduction}

The mechanisms of liberal intergovernmentalism refer to the impact of increasing exchange on the ability of states to deal with higher levels of complex interaction. The universal need for states to export some goods and services leads to trade liberalisation which, in turn, promotes regional integration. Mercosur is one of the biggest regional integration schemes in the world. The fact that it has existed for about a quarter of a century attests to the fact that it has positioned itself successfully and effectively in the international community. However, it has not managed to avoid the problems typically experienced by regional integration schemes. Despite some initial success in its earlier years, it is currently experiencing serious technical problems that could hamper its further development. The formation of additional instruments in recent years - which could be described as 'institutional hypertrophy' - has not worked to resolve these problems and advance the process of regional integration.

Role players in Mercosur are restricted to high-level authorities in the governments of member states. Private sector role players, such as class associations, industrialists, workers, businessmen, consumers, taxpayers, farmers and bankers, were not consulted, either when the two main players - Argentina and Brazil - took the first steps towards forming Mercosur, or at any time thereafter. This is not to say that their interests have not been considered at all; indeed, it is incumbent upon member states to support and promote the interests of their own private sectors. However, decision-making has been vertical in

* Centro Universitário de Brasília (UniCeub), Brasília-DF, Brazil; ricardo.caichiolo@gmail.com. 
that, in some instances, states have taken decisions on behalf of their private sectors that were criticised by those same sectors the state was trying to promote and defend. This has amounted to a state-led integration process, with limited participation by civil society. To some extent, this is a legacy of the era of military rule, especially in Mercosur's early years.

From a neofunctionalist perspective, one causal factor that should interact with two others is absent in the case of Mercosur: the creation of supranational market rules in the place of national regulatory regimes. The intergovernmentalist model adopted by Mercosur does not lead to any kind of supranational institution. In addition, supranationalism is not envisaged by any of its member states. Political loyalties have not been transferred to supranational agencies, and regional institutions remain weak. The process of institutional hypertrophy has not solved the bloc's inherent problems, and the dynamics surrounding it have depended on the arbitrary initiatives undertaken by presidents of member states.

The other two elements of the neofunctionalist model of regional integration that should interact with supranationalism are the growing economic interdependence of countries in a given region, and the organisational capacity to resolve disputes among them and build international legal regimes (Cavlak 2014). However, neither of these elements can be identified in Mercosur, as we will indicate below.

Before proceeding towards a deeper analysis of the process of regional integration in Mercosur, it will be useful to review various approaches to the study of regional integration. Studies of regional integration have proliferated since the early 1990s mainly because of the deepening of the integration process in the European Union (EU). The federalist theory of Etzioni, the behaviourist transactionalism of Deutsch, and the neofunctionalism of Haas are evident in those studies, and those classical concepts still seem to form the theoretical base of more recent studies.

Although Haas's work dates back to the 1950s, some of its postulates are still visible in current debates about regional integration, and its explanatory power in respect of the progressive institutionalisation of Europe is undeniable. Neofunctionalism developed as a critique of functionalism (Pentland 1973), and must be situated in the historical development of the EU in the 1960s. In fact, the neofunctionalist analysis strongly resembles the Monnet method, as Robert Schuman considered that 'Europe' would be achieved through strategic and incremental means (Battistella 2003).

Neofunctionalist studies should be viewed in the context of pluralism and the behavioural movement in political science. Those studies sought to be scientifically verifiable and to apply to other processes of regional integration besides the European one. The first main expression of the neofunctionalist theory was Haas's study of the development of the European Coal and Steel Community (ECSC), The Uniting of Europe (1958), followed by The Political Dynamics of European Economic Integration by Leon Lindberg (1963).

Neofunctionalists argue that, while different groupings within nation-states have different interests and behave in different ways, they are able to organise across state boundaries, leading to the formation of supranational institutions. As Haas put it, national groups 'tend to unite beyond their former national confines in an effort to make common policy and obtain common benefits' (1958: xxxiii). However, this has not happened in Mercosur. 
The neofunctionalists also argued that, in the course of the European integration process, differences among nation states did not hamper the establishment of a higher authority in the form of the ECSC. As noted by Haas (1958: 162), 'fragmentation was and is typical', which means that the process of integration is not automatic. Neofunctionalist theory recognises the importance of the political dimension in the process of regional integration, and states that the path to political integration must be supported by institutional co-operation (Lindberg and Scheingold 1970). The establishment of formal institutions plays a vital role in sustaining and guaranteeing agreements among nation-states.

As regards Mercosur, it seems that neofunctionalism has influenced perceptions of the integration process, leading to the 'artificial' creation of a number of institutions meant to drive the integration process. However, the establishment of various bodies with limited performance, low levels of representation, and technical and budgetary shortcomings has not worked to achieve the desired result.

The 1970s and 1980s were dominated by Europessimism and Eurosclerosis, with politicians and academics alike losing their faith in European integration. However, following the approval of the Single European Act (SEA) in 1986, there was a dramatic swing in the debate, with Europessimism changing into Europtimism. At that point, renewed intergovernmentalist theory emerged, mainly in the work of Moravcsik. While generally classified as 'liberal intergovernmentalism', Moravcsik described his own work as 'intergovernmental institutionalism' (1991: 25). He was also strongly influenced by the two-level game approach in the work of Robert Putnam (1988).

\section{Liberal intergovernmentalism and Mercosur}

Moravcsik brought some new concepts to intergovernmentalist theory, specifically in the course of examining the relaunch of the EU. The main difference from classical intergovernmentalist theory is that supranational institutions can play a role in regional integration processes, albeit in a limited way. They can reinforce interstate agreements as a basis for integration, and nation-states can profit from them for the purposes of domestic legitimation and the pursuit of their domestic preferences.

Moravcsik strongly defends the importance of two components of the integration process: bargaining among nation-states, and national preference formation. In his view, the formation of national preferences results from interaction between society and government. As an intergovernmentalist liberal, Moravcsik accepted multicausal explanations of the phenomenon of regional integration, and confirmed the postulates of both neorealists and neoliberals by accepting that states were the main actors in the integration process, but that the process was largely driven by economic interests. In this perspective, integration in Europe could be quickly explained as a 'series of rational choices made by national leaders' (Moravcsik 1998: 18), which were previously restricted to their domestic terrains alone.

Mercosur can be viewed through an intergovernmental liberal lens: the main actors have been and remain its member states (particularly Argentina and Brazil), and economic interests are the main drivers that move the process forward - or at least keep it alive. 
Moravcsik (1998) displayed a liberal vision of integration, and the primacy of relationships between social groups. He used liberal theory to empirically explain the relationship between state and society. For him, liberal theory is the starting point for studying international politics, aimed at illuminating the interactions among social groups such as employers, unions, political parties, and churches, and their influence over state decisions. In order to rectify the theoretical failure to address these dynamics, Moravcsik developed a state-centric approach which he labelled 'liberal intergovernmentalism'. First, he connected a liberal theory of national preference formation (i.e. 'domestic politics') to an intergovernmentalist analysis of inter-state negotiations in a two-level game, and then added a regime theory component. In this approach, states, as rational decision-makers, are prepared to relinquish aspects of their sovereignty in order to increase the efficiency of inter-state co-operation. They accept this diminution of their sovereignty because EU institutions 'strengthen the autonomy of national political leaders vis-à-vis particularistic societal groups within their domestic polity' (Moravcsik 1993: 507).

Mercosur's institutions are weaker than those of the EU. Despite its hypertrophy, its institutions lack the autonomy (and the budgets) to implement decisions affecting all member states. Again, concentration of power in the presidential realm is found at every turn. However, Moravcsik also regarded the preferences of states and the way in which they were internally configured as central to understanding international politics. While institutions and social groups were largely responsible for shaping and influencing state preferences, he argued, they could not be explained without taking into consideration domestic social contexts as well as transnational relations. This led to Moravcsik opening the 'black box' of the state in order to identify its internal characteristics. In an article on the Franco-German wars, Moravcsik (1993) analysed the activities of different social groupings and their insertion into domestic policy, which, he believed, had a significant impact on the state decision-making process.

In liberal theory, state preferences rest on domestic relations among interest groups as well as international relations. Moravcsik emphasised the primacy of the former, in order to point out that the state is not the only actor and decision-maker in the international realm. Instead, he argued, state preferences result from interactions among (largely economic) domestic interest groups, which articulate internally and externally, and influence high and low politics. He also argued that there was no national harmony or single national sentiment capable of homogenising domestic demands, since economic and political resources were scarce, and therefore strongly contested. Thus the internal environment could be seen as one of political contestation among diverse interest groups, which implied the need for constant negotiations.

In this view, government decisions result from multiple interactions among a range of domestic actors, all pursuing their own interests. These interests can be advanced more or less successfully, depending on financial resources as well as political influence. There is no single national interest; instead, after a struggle among domestic groups, the most powerful would move towards accomplishing its preferences. The state, as a representative institution, changes constantly. If the state is a democracy, it is subject to regular shifts in preference, as rulings groups are periodically replaced, and new 'chief executives' (heads 
of state or government) elected or appointed. Influence over the state therefore depends upon the interaction among social groups, and their command of resources. In this analysis, Moravcsik considered the roles played by these social groups, and the intense domestic contestation among them over scarce or abundant resources.

In liberal intergovernmentalism, there is a direct connection between interdependence and the international system. States are shaped not only by domestic actors, but are also influenced and constrained by the international system. Moreover, each state makes an effort to demonstrate its preferences externally. This will eventually impact on the preferences of other states, especially those that are less powerful.

Thus, the same disputes that take place at the domestic level also occur at the international level. The greater the relative power of a state, the easier it will be for it to show its preference externally. This preference will prevail over those of less powerful states. Moreover, it is possible to establish a causal link as well as mutual interaction between the international and national levels. According to Moravscik, the preference of a state in the domestic realm is comparable to the influence of a more powerful country over a less powerful one. The latter has to readjust its preferences. Therefore, the domestic level can exert influence over the international level, and vice versa. Without such a causal relationship, these levels would not even exist; they cannot exist without one another.

Moravcsik argued that liberal theory had wider implications, even under adverse circumstances, such as the existence of relatively few liberal countries, as it explains variations in foreign policy in terms of internal contestation, and links them to the preferences of influential social groupings. He also explains changes in political representation and the preferences embodied in state decisions in this framework, showing that power is still able to explain historical changes in the international system. In this respect, Moravcsik again recognised the centrality of the bargaining process, which can change state behaviour within the international system.

The movement towards regional integration that resulted in the formation of Mercosur began in the 1980s, driven by major changes in the international environment, notably the end of the Cold War, and the need to restructure South American countries after the era of dictatorships. Some Latin American states decided to address shared problems such as high inflation rates, protectionism, and unemployment by developing closer interstate relations. The belief grew that these emerging common interests could be more effectively addressed through convergence and co-operation among countries in the region. In the liberal intergovernmentalist perspective, co-operation among states was possible because of converging interests and the domestic articulation of certain social groupings, notably entrepreneurs and political parties. Argentina and Brazil - the leading role players - decided to establish Mercosur before their democratic transitions.

The Tripartite Agreement Corpus-Itaipu, signed in 1979 by Argentina, Brazil and Paraguay (which resulted in the construction of the Itaipu Binational Hydroelectric Dam, which Brazil and Paraguay share), dispelled suspicions over Brazilian intentions in the region. Just two years before, on 31 July 1977, Argentina closed its border with Brazil due to a dispute over the exploitation of the Paraná River (Krishna-Hensel 2012). After the dam was built, Brazil imported cheap Paraguayan energy, which helped to strengthen its 
industrial parks, and maintain its economic lead over Argentina in terms of technological development.

Another sensitive issue, namely the use of nuclear power, was resolved via agreements between Brazil and Argentina from the early 1980s onwards. This had been a real concern, especially for Brazil, as Argentina, despite its inferior economic position, had kept up its advantage in nuclear technology. On 17 May 1980, the Brazilian and Argentine foreign ministers, Ramiro Saraiva Guerreiro and Carlos W Pastor, signed a Cooperation Agreement between Brazil and Argentina for the Development and Application of the Peaceful Uses of Nuclear Energy, taking into account the previous Treaty for the Prohibition of Nuclear Weapons in Latin America (also known as the Treaty of Tlatelolco).

Their new relationship was strengthened further when, in 1982, Brazil supported Argentina when the latter demanded that Britain relinquish control of the Falkland Islands. The dispute, which led to the Falklands War, arose when the Brazilian government would not allow British aircraft flying to the South Atlantic to land regularly on its territory. In the mid-1980s, both countries agreed to defend the principle of non-intervention and to support the Contadora Group, established by Colombia, Mexico, Panama and Venezuela in response to the interventionist Central American policy of US President Ronald Reagan, which began with the American invasion of Grenada in 1983. Eventually, Argentina, Brazil, Peru and Uruguay participated in the Contadora Support Group. Therefore, the convergence between Brazil and Argentina was not restricted to the post-dictatorship period only.

On 30 November 1985, following their democratic transitions, the Brazilian and Argentine presidents, José Sarney and Raúl Alfonsín, signed the Treaty of Iguaçu, the first step towards establishing Mercosur. The decision to embark on a path to regional integration was taken at the presidential level. As noted previously, in the liberal intergovernmentalist perspective, co-operation between states is possible when their interests converge, and this seemed to be the case from the mid-1980s onwards, following the domestic political changes in both countries. In a difficult international economic climate, Argentina and Brazil realised they could benefit from a stable and lasting alliance. Their convergent interests lay in the fact that both were in a post-dictatorship period, and both had to deal with a challenging external environment. As noted earlier, mutual suspicions about the Parana River and the use of nuclear energy had abated. Both had introduced failed plans to control inflation - the 1986 Cruzado Plan and 1987 Bresser Plan in Brazil, and the 1985 Austral Plan in Argentina.

While Brazil faced some economic problems, it had already achieved a high level of industrialisation, largely due to measures adopted after World War II which were not seriously disrupted even in the era of military governments. By contrast, the Argentine dictatorship, mainly between 1976 and 1983, had ruined the country's industrial base, and reinstated the primary export model of the late 19th century. Under these circumstances, Argentina could no longer lay claim to sub-regional leadership. Brazil's dominant position in the region became incontestable, even though it usually shied away from displaying this openly, for fear of alarming its neighbours. 
These asymmetries between Argentina and Brazil (later involving Paraguay and Uruguay as well) did not prevent a mutual approach; on the contrary, both countries sought complementarity, through the decisive roles of their presidents, despite business fears of external competition, especially in Brazil.

At this point, it is important to identify two deeply embedded historical features of South and indeed Latin American politics, namely centralism and personalism, and their impact on regional integration. The outcomes are weak regional institutions, which have no real power or autonomy vis-à-vis the executive power of member states. An allied historical feature of South American politics is that legislatures do not play a significant role in foreign affairs. This is due to the excessive concentration of power in the executive branches of Latin American countries, not only during dictatorships, but also in democratic constitutions. This amounts to a negative feedback mechanism: the concentration of power in the executive branch of government hampers legislative interest in foreign affairs; at the same time, legislative branches believe they are incapable of playing a significant role in foreign affairs, thus reinforcing the trend towards executive domination.

During the convergence between Argentina and Brazil in the 1980s, the primacy of governmental actors can be seen in the first acts passed by Sarney after assuming the Brazilian presidency. Sarney worked actively to resolve some problems related to trade barriers between the two countries. For instance, in February 1985, the Brazilian government had restricted the importation of apples, fresh garlic and fish from Argentina. It imposed a quota of 280000 boxes of apples a month (non-cumulative zero rate), while the Argentine government had expected to export 500000 boxes a month. Two months later, the Argentine government decided to suspend the importation of bananas and coffee from Brazil, which was seen as a retaliatory measure. The Brazilian government argued that Argentina was not a producer of bananas and coffee, so it could not invoke the clause from the Latin American Integration Association (LAIA), or Associação Latino-Americana de Integração (ALADI), which allows countries to safeguard national industries by raising trade barriers. At the time, the Argentine Ambassador to Brazil, Rafael Vazquez, confirmed that the suspension was due to the large deficit in bilateral trade.

In the third week of July 1985, Sarney authorised the extension of Partial Scope Agreement No 1 (which had expired on 30 June 1985) until 31 December 1985, as well as the importation of 1,3 million tons of wheat (compared to 800000 tons in 1984) and crude oil. As a result, the two countries agreed to buy more goods from each other in the case of a negative balance of trade exceeding 50 million dollars (Hirst and Lengyel 1986).

A few months later, on 30 November 1985, Argentina and Brazil signed the Declaration of Foz do Iguaçu, regarded as the foundation of a new era in bilateral relations. It started a process with two main strands. The first was the negotiation of economic agreements aimed at integrating their economies. Initially, instead of entering into a broad and ambitious agreement, they decided to concentrate on particular areas, such as the automobile industry, which could be a starting point for creating a web of common interests. The second was co-operation in the field of nuclear activities. After the ceremonial inauguration of the Tancredo Neves Bridge, which links the cities of Foz do Iguaçu (Brazil) and 
Puerto Iguaçu (Argentina), the two countries decided to establish a joint commission to study high-level co-operation and integration.

On 29 July 1986, in Buenos Aires, Sarney and Alfonsín signed the Argentina-Brazil Integration and Economics Cooperation Programme (Programa de Integración y Cooperación Económica Argentina-Brasil, or PICE), which led to 24 protocols during the next two years. They were eventually absorbed into Economic Complementary Agreement No 14, signed in December 1990 within the ambit of LAIA, the forerunner of Mercosur.

The protocols were aimed at creating an integrated economic space with a stronger presence in world markets. Both countries were experiencing severe economic crises, and integration appeared to offer a way forward, and of increasing their participation in international decisions. According to Moniz Bandeira (2001), there was an emphasis on the integration of the capital goods sector, which was crucial for heavy industry and for technological development.

In addition, the governments of Brazil and Argentina concluded that neither of them could intervene in the world order, or had enough power to influence international decisions affecting Latin America, especially those related to trade protectionism, foreign debt, and the unstable prices of imported products. This led to a gradual and selective opening up of their economies, aimed at making them more competitive. In this spirit, on 29 November 1988, they signed an Integration, Cooperation and Development Treaty.

This convergence between the two countries provoked some fear in the Argentine business sector, since Brazilian production processes were cheaper and more efficient, achieving greater economies of scale. Moreover, Brazil's penetration of foreign markets was stronger than Argentina's. Argentine business leaders feared that this could lead to a situation of structural inequality, in which Argentina would exchange primary products unequally for Brazilian manufactured goods. However, the Argentine and Brazilian governments unanimously defended the strengthening of bilateral relations. The internal and external environments favoured this new approach. Sarney and Alfonsin believed strongly that gradual economic integration was the best way of overcoming the economic crisis, marked by difficulties in repaying foreign debt and high rates of inflation. Moreover, it seemed clear that countries would need to adapt to the rapidly unfolding post-Cold War order, marked by economic liberalisation, globalisation, and the use of advanced technologies.

Thus Argentina and Brazil overcame their historical rivalry by embarking on a project of economic integration, culminating in the Treaty of Asunción in 1991, which established Mercosur. The participation of Paraguay and Uruguay must also be understood in terms of intergovermentalism, as both those countries responded to the pressures of economic necessity. Particularly for Paraguay, which does not have its own access to the sea, Mercosur has become an essential avenue for participating in world trade.

From a political perspective, Argentina and Brazil wanted to increase their bargaining power by creating a regional bloc that would have a stronger presence in the global market, with a greater degree of autonomy. Both countries sought to preserve the principles of universalism and autonomy, even after signing the Treaty of Asunción, as globalisation and regionalisation are not mutually exclusive. The original idea was that regional 
integration via Mercosur would not limit the marge de manoeuvre of member states, their administrations or their entrepreneurs. These principles have been preserved until today, as Mercosur member states remain resistant to institutionalisation.

Paraguay and Uruguay also saw Mercosur as an instrument for aggregating forces and co-ordinating positions. With reference to Moravcsik, Mercosur came into being at a historical moment when domestic and external political circumstances were favourable. Liberal intergovernmentalism argues that an institution can be created if states believe it will harmonise their preferences. In a sense, Mercosur resulted from such a belief. The four members believed it would facilitate trade among them, but this would largely benefit Argentina and Brazil, and particularly the latter. They also saw Mercosur as a means of gaining a stronger voice and greater bargaining power in the international arena.

Each member state focused on specific economic and political gains. It can be assumed that Mercosur had political as well as economic dimensions, as the interests of member states at the time of its formation could be classified in both terms. Brazil's political and economic interests were the strongest, as it regarded Mercosur as a means of gaining a stronger presence in the world order by advancing a process of regional integration in the Southern Cone. As the dominant subregional power, Brazil expected Mercosur to improve its bargaining power vis-a-vis the major powers, particularly the USA.

\section{The black box of Mercosur: a continuous state-led process}

Moravcsik (1998) underlines the primacy of social groups and the need to open the black box of the state to in order to show that the state is not the only decision-maker in the international arena. Domestic groups such as political parties, NGOs trade unions and social movements articulate domestically and externally and have an impact on decisions in numerous areas, influencing high and low politics in the process. According to Moravcsik, the scarcity of economic and political resources leads to the absence of domestic harmony. There is no single national feeling able to standardise all domestic demands. Political disputes constantly occur, and negotiations among domestic actors are essential. Therefore, there is a need to open the black box of Mercosur member states in order to establish whether, and how, their main social groups have influenced aspects of domestic politics related to the regional integration process.

In line with the neoliberal philosophy of the 1990s, the primary objectives of all member states have been to free intra-regional trade, create incentives for developing national production, and attract foreign investment. Therefore, it seems plausible to assume that domestic groups, such as exporters and importers, actively participated in the first steps to open up intra-regional trade. According to Cervo,

Brazilian society, through its associations - farmers, industrialists, businessmen, traders, exporters, workers - put pressure on the decision-making process in order to dose the opening with the adaptability of its segments (Cervo 2008: 165). 
However, contrary to Cervo's assertion, the active participation of Brazilian society - and the societies of other member states - has been very limited. While a few private sector segments have participated in regional decision-making processes, the decision to sign the Treaty of Asunción (1991) was taken by high-level government officials, without involving or considering other domestic actors.

From then until the end of 1994, representatives of economic sectors that were negatively affected by the abolition of trade barriers began to complain and participate in a more active way. While the two largest sectors, i.e. automotive and sugar, were relatively unaffected, problems were experienced in respect of wheat, wheat flour, powdered milk, steel, spark plugs, paper and paperboard, textiles, leather, footwear, fruit, garlic, capital goods and electronics. In addition, Argentina strongly criticized a Brazilian decision at the beginning of 1992 to open new credit lines for exports and industrial investment. Following the Ouro Preto Protocol, signed at the end of 1994, sensitive products were entered on a List of Exceptions and a Regime of Final Equation, which were filed with the Customs Union. Besides the automotive and sugar sectors, these have large been capital goods, computers, telecommunications equipment, steel, textiles and footwear (Mendes 2001).

Civil society participation has been limited by a lack of financial resources and a lack of knowledge. Thus, the situation in Mercosur is quite different to that identified by Moravcsik in respect of the EU: domestic groups are largely disjointed, and have limited impacts on decision-making. The governments of member states decide which policies will be adopted; in an attempted process of rational decision-making, their executive arms decide themselves which measures would benefit certain sectors of society.

The notion of deepening regional integration via active social participation is absent from Mercosur. The idea of regional integration was never fully absorbed by the elites or civil society of member states. Brazil, the dominant regional power, which could act as the engine of regional integration, as Germany and France have done in the EU, remains attached to its principles of autonomy and universalism.

In The Choice for Europe (1998: 123), Moravcsik says the British government's decision in the 1950s not to join the Common Market was 'the rational one for a government that traded little with the Continent, had high tariffs in place, and feared competition with German producers.' Along similar lines, it is rational for the Brazilian government to restrict Mercosur's institutionalisation. This is deliberately done in order to safeguard the principles of autonomy and universalism which the Brazilian government believes it needs to achieve other global goals.

Moravcsik (1993) notes that the resources needed for negotiations are often limited, and depend on the rational choices of states. Contrary to the situation which Moravcsik identified in the EU, in which the rational choices of states were defined by bargaining among domestic social groups such as entrepreneurs, political parties, multinationals and NGOs, high-level officials and presidents are in charge of those choices in Mercosur. This is not to say that governments simply ignore the perceptions and demands of domestic groups - in fact, domestic groupings make few or no demands. And those that do, demand the maintenance of the status quo - i.e. the intergovernmentalist model of integration. 


\section{The limited participation of civil society}

Brazilian diplomatic records and interviews with government officials and private sector representatives confirm that, despite efforts to involve civil society from the mid-2000s onwards, executive role players have been the main decision-makers in respect of Mercosur. While civil society participation has grown, its influence over the decision-making process is still limited.

Diplomatic records were examined to trace Mercosur's development, notably the main areas of interest of member states. They mainly deal with regional trade and development, and, to a lesser extent, democracy.

Bilateral relations between Argentina and Brazil - including new themes and issues since those discussed during the 1980s - have spilled over to the whole bloc, with the addition of a bureaucratic structure to support the integration process. In line with the notion of institutional hypertrophy, advances have largely been quantitative rather than qualitative. The records also show that deepening the integration process has been out of the question, and that establishing an intergovernmental system has hardly been discussed, with few references to supranationalism.

There are many references to trade, an area of major concern for all member states. More recently, Uruguay in particular has demanded the right to sign bilateral agreements with third parties. Common trade themes are the Common External Tariff (CET), agriculture, industry, exceptions to the Customs Union list, the Customs Code, safeguards, services, production chains and competitiveness.

By contrast, 'civil society' is practically absent from the diplomatic documentation. In order to quantify this, I counted the number of times the term 'civil society' occurs in relevant documentation. To this end, I examined both open and restricted documents sent and received by BRASALADI, Brazil's permanent mission at LAIA / ALADI, in a relevant period. This archive holds accumulated information about the main events and decisions related to Mercosur as a whole, covering all four member states. The open documentation covers the period from 1995 to February 2015, and the restricted documentation covers the period from 1995 to 2009 . The results appear in Table 1.

It shows that the term 'civil society' only appeared on 28 of 2119 pages of open documents between 1995 and 2011. In fact, the first time the term was used was on 1 December 2000, a day after a critical panel discussion about the relaunch of Mercosur by representatives of Argentine civil society. The then president of the Chamber of Exporters of Argentina, Enrique Mantilla, criticized the absence of clear rules for common trade policies in Mercosur and the lack of transparency of decision-making bodies, which, he said, had led to the existence of a kind of 'negotiators' club' that was almost impermeable to the participation of civil society. In addition, Professor Manuel Mora y Araujo, an Argentine sociologist and director of a public opinion research institute, described the feeling of the people of Argentina as one of 'frustration'. He based this conclusion on surveys of public opinion about the benefits of participation in Mercosur. In 1991, at the time of Mercosur's formation, approval ratings were $80 \%$; by 1996 it had declined to $67 \%$, and by 2000 to $49 \%$. ${ }^{1}$ 
As regards the restricted documents, the term 'civil society' appeared for the first time on 27 May 1998 as a reference to the creation of 'MercoNet' (Red MERCOSR), an initiative of researchers in the region to establish an academic network. This was a significant grouping, supported by the International Development Research Centre (IDRC) of Cana$\mathrm{da}$, that originally comprised nine institutional members.

Table 1: Incidence of the term 'civil society' in diplomatic documents held by BRASALADI

\begin{tabular}{lcc} 
Year & Occurrence (number of pages) & \multicolumn{1}{l}{ Total pages } \\
\hline \multicolumn{3}{c}{ Open documents } \\
\hline $2995-2011$ & 28 & 2119 \\
\hline 2012 & 11 & 1294 \\
\hline 2013 & 16 & 1176 \\
\hline 2014 & 2 & 776 \\
\hline $2015 *$ & 2 & 64 \\
\hline
\end{tabular}

\begin{tabular}{lcl}
\hline & Restricted documents & 671 \\
\hline $1995-1996$ & 0 & 693 \\
\hline 1997 & 0 & 404 \\
\hline 1998 & 1 & 449 \\
\hline 1999 & 3 & 266 \\
\hline 2000 & 0 & 207 \\
\hline 2001 & 0 & 62 \\
\hline 2002 & 0 & 462 \\
\hline 2003 & 5 & 425 \\
\hline 2004 & 7 & 508 \\
\hline 2005 & 5 & 352 \\
\hline 2006 & 12 & 281 \\
\hline 2007 & 6 & 309 \\
\hline 2008 & 0 & 289 \\
\hline 2009 & 0 &
\end{tabular}

Source: Calculated by author, based on documents held in the Itamaraty Historical Archive in Brasília.

Given these results, it is fair to conclude that the participation of civil society in Mercosur has not been a priority. The increased use of the term in 2006 was due to an initiative by the president of the Commission of Permanent Representatives of Mercosur (CPRM) to solicit preliminary ideas about the establishment of a social institute within Mercosur. These ideas were developed in a brief document by Bernardo Kliksberg, an Argentine sociologist and economist. After drawing attention to the challenges of fighting poverty 
and exclusion, he went on to state that a social institute in Mercosur could provide a research locus for people responsible for designing and implementing policies and social programmes. According to him, such an institute could comprise a common social 'think tank' that would facilitate the elaboration of joint projects and epistemic networks. The establishment of a Mercosur Social Institute (Instituto Social del Mercosur) was approved on 16 June 2007 (Decision CMC No. 3/07), during the XII Meeting of Ministers and Authorities of Social Development of Mercosur and Associated States.

However, despite this initiative, the use of the term 'civil society' declined again in the following years. A social dimension to Mercosur was developed in the form of the Mercosur Institute for Public Policy and Human Rights (Decision CMC No. 40/04); the Mercosur Structural Convergence Fund (Decision CMC 45/04); the Constitutive Protocol of the Mercosur Parliament (2005); the Mercosur Social Summits (held since 2006); the Mercosur Democracy Observatory (Decision CMC No. 24/06); the Coordination Commission for Social Affairs Ministers (Decision CMC No. 45/10); and the Mercosur Social Participation Support Unit (Decision CMC No. 65/10). However, while civil society participation has improved in quantitative terms, it has not improved in qualitative terms.

'Qualitative' institutions are those that are truly representative of civil society in member states, and collaborate meaningfully to strengthen the regional integration process. However, there is little point in establishing these sorts of institutions if they have no meaningful powers. The move to establish these forums was led by the governments of member states, and did not spill over on civil society in those countries. Thus the evolution of Mercosur and the participation of civil society cannot be explained in terms of neo-functionalism, as its workings largely reflect the interests of member states.

\section{Mercosur's commercialist features}

Mercosur continues to display a low level of institutionalisation, with decision-making power vested in its member states. When Alfonsín and Sarney set Mercosur in motion, they recognised that this would initially need to be a state-led process. However, they believed this would eventually ignite a neofunctionalist spill-over effect in that regional integration would increasingly be driven by business interests, which has not occurred. On the contrary, the business sector as a whole has largely continued to adhere to the economic development paradigm of the second half of the $20^{\text {th }}$ century, in which some countries in the region were modernised in terms of the theory of import substitution proposed by the Argentine economist Raúl Presbisch and the Economic Commission for Latin America and the Caribbean (ECLAC).

However, two key features of this approach was that the transformation of Latin American industry was driven by foreign instead of domestic enterprises; and that major economic sectors, notably railways, port services, water, gas, electricity, mining, chemicals, and developmental services, were developed by public instead of private enterprises. In most cases, this was not due to deliberate government decisions but the weakness of the private sector, which is a characteristic of most Latin American countries. As a result, the 
gradual transfer of decision-making from member states to regional structures as envisaged Sarney and Alfonsin has not yet occurred.

Again, this fits Moravcsik's observation (1993) that direct negotiations among member states could be a way of controlling process, mainly in regional groups where there is a low level of institutionalisation.

\section{Policy co-ordination}

In line with the model of liberal intergovernmentalism, Mercosur is a good example of low levels of regional institutionalisation, with regional affairs conducted via direct negotiations between the governments of member states. This suits the interests of the larger member states which are able to control the rhythm of the integration process, favouring their domestic interests. While, for Brazil, Mercosur is primarily an instrument for increasing its regional and international stature, for Argentina, Paraguay, Uruguay and Venezuela, it is an important trade market above all. Given the asymmetries among member states, larger countries accept the idea of co-operation with a minimum loss of sovereignty as a way of controlling the course of the integration process, according to national interests.

A content analysis of Brazilian foreign policy discourse about Mercosur reinforces the conclusion that key role players have continued to opt for intergovernmentalism rather than moving towards supranationalism. ${ }^{2}$ This was done by counting references to 'supranationalism' in all the speeches about Mercosur made by Brazilian presidents from the signing of the Treaty of Asunción in 1990 up to 11 April 2016. The results are recorded in Table 2. It shows that Brazilian presidents use skillful rhetoric to advance their overarching political goal of retaining Mercosur's intergovernmentalist status quo.

Table 2: Incidence of the term 'supranationalism' in speeches by Brazilian presidents related to Mercosur, 1990 - April 2016

\begin{tabular}{lccc}
\hline Presidents & Period & Number of speeches* & Mentions \\
\hline Fernando Collor de Melo & $1990-1992$ & 0 & 0 \\
\hline Itamar Franco & $1992-1994$ & 2 & 0 \\
\hline Fernando Henrique Cardoso & $1995-2002$ & 12 & 1 \\
\hline Luis Inácio Lula da Silva & $2003-2010$ & 21 & 1 \\
\hline Dilma Rousseff & $2011-$ present** & 10 & 0 \\
\hline
\end{tabular}

* Only speeches related to MERCOSUR. ** Up to 11 April 2016.

Source: Compiled by the author, based on the following websites: http://www.biblioteca.presidencia.gov.br/ ex-presidentes; http://www2.planalto.gov.br/acompanhe-0-planalto/discursos/discursos-da-presidenta [accessed on 11 April 2016].

The term 'supranationalism' occurred in only two of the 45 speeches. The first was a speech by Fernando Henrique Cardoso on 21 June 2001 at the XX Meeting of the CMC and Summit of Mercosur Heads of State, in Asunción (Paraguay), in which he declared: 
I want to tell you, with my full conviction: I have a vision for the future of Mercosur. An entity whose potential goes beyond trade: the deep integration of competencies in the economy, including monetary, and growing unity on the political level, a construction that, in due course, will find expression in supranational institutions. Compared to the greatness of these objectives, the immediate and particular interests - as important they may be - become less significant. We should not be victims of a demonization of particular interests. Mercosur is the work of democracies, not technocracies [...] (author's emphasis).

It took more than five years for the term 'supranationalism' to reappear in a speech by Luis Inácio Lula da Silva, on 19 January 2007 during the XXXII Mercosur Summit in Rio de Janeiro (Brazil). On that occasion, he affirmed that:

Political and ideological pluralism are fully compatible with our integration process, which seeks development, social inclusion, employment and the strengthening of democracy. There has never been a political climate as favourable for our integration. In Cordoba (Argentina), I said that we should gradually move toward supranationalism, as has occurred in other integration experiences. Therefore, we strongly support the institutional strengthening of Mercosur (author's emphasis).

Political leaders of member states speak about Mercosur and the merits of greater regional integration in eloquent and rhetorical terms. However, in practice, Mercosur's 'construction' is limited by budgetary constraints as well as domestic political interests (Cervo and Lessa 2014). Therefore, contrary to the expectations of Alfonsín and Sarney, Mercosur remains a 'commercialist' enterprise, focusing on trade. The economic development envisioned by these leaders has simply not occurred: governments have not been strong enough to promote the productive integration of member states on their own. The private sector or sectors in the region - which have historically depended on promotion of the state, and can be described as 'inert', 'non-dynamic' and 'lazy' (Interview with Amado Cervo) - have, in general, ignored Mercosur.

Few private enterprises in the region have become competitive enough to internationalise, and enter global markets. Initial efforts to broaden their scope focused on South American countries only. However, as local economic conditions deteriorated, capital in the region was diverted to the USA, Canada, China, the EU and Africa. Some Brazilian companies, in collaboration with the Brazilian government, have attempted to realise their 'globalist vocation. However, during the presidencies of Néstor (2003-2007) and Cristina Kirchner (2007-2015), Argentina turned into a bankrupted, protectionist and introspective state which was in no economic condition to do so. In fact, Mercosur has become a millstone around Brazil's neck, as it cannot sign bilateral trade agreements with third 
parties, including the EU: thus far, Mercosur member states can only negotiate joint trade agreements with third countries, or groups of countries.

Argentina and Brazil are the backbone of Mercosur, and the erosion of this alliance would have a strong impact on the bloc. Mercosur decisions are reached by consensus among member states. The Brazilian government has claimed that Argentina has changed its stance on Mercosur in recent years, which has hampered the conclusion of a free trade agreement with the EU. Moreover, following the inclusion of additional members, consensus has become more difficult to achieve. The problem is that the broadening of regional integration has complicated the economic agenda even further. Indeed, one of the main reasons for the current situation is the different economic models pursued by member states.

\section{Conclusion}

Regional integration via Mercosur has not developed sufficiently to create its own dynamic, as suggested by the neo-functionalist model. There is no spill-over effect that furthers the process of integration; Mercosur has not, over the years, developed harmonised rules of trade that could replace national regulatory regimes, or integrated social or labour market policy. There has been no convergence among domestic economic sectors that could be regarded as the engine of further regional integration. Levels of regional economic complementarity are low, and the integration process is controlled by the presidents of member states. Mercosur's main achievement has been to create a better political understanding among its members.

Some regional institutions have been created, notably the Mercosur Parliament, but they remain weak, and there is a lack of strategic planning aimed at improving intraregional development as well as the bloc's international insertion. This is demonstrated by the excessive delays in reaching a free trade agreement with the EU. According to Moravcsik (1998), state decisions are influenced by domestic groupings. However, in several instances, the policies and decisions of Mercosur member states have not reflected those of domestic interest groups.

There are intensive discussions in the Brazilian private sector about the need to abolish the poorly functioning Mercosur Customs Union, and create a free trade area instead. According to them, Mercosur has complicated trade relations with the USA and EU, resulting in Brazil being the only major world economy that does not participate in or benefit from major international trade agreements.

Instead, contemporary choices by Mercosur member states can only be explained in terms of high politics, and its intergovernmental model is determined by national leaders. Given the absence of effective civil society participation, power in Mercosur is centralised in the hands of the executive heads of member states. In fact, despite conforming to Moravcsik's theory of liberal intergovernmentalism in some respects, the current institutional set-up is inefficient. 
Mercosur has established some institutions regarded as central to regional integration. Theories of international relations and the EU experience have shown that that these institutions assist the implementation and interpretation of international laws. However, two important components of regional integration emphasised by Moravcsik - effective bargaining among member states, based on the formation of national preferences - have been lacking in recent years. Bargaining has been adversely affected by tensions among member states, notably Argentina and Brazil. According to Merriam-Webster, a bargain is 'an agreement in which people or groups say they will do or give something in exchange for something else.' In recent years, however, the former Argentine president Cristina Kirchner in particular abandoned 'bargaining' in favour of unilateral action. There was no longer an 'exchange for something else.'

The formation of national preferences has been hindered by the prevalence of the state, and the lack of participation of civil society. Therefore, Mercosur represents a typical state-led regional integration process. Domestic drivers of integration are politically and geographically limited by the excessive emphasis on the role of the executive branches of member states. They remain the most important - and often the sole - actors defining the path of integration, via presidential diplomacy.

Despite their high-flying rhetoric, Mercosur's supposed protagonists have done little to improve the organisation in practice, leading to its steady decline. Talk about expanding Mercosur is little more than yet another rhetorical flourish.

\section{Notes}

1 Document from José Artur Denot Medeiros, Ambassador, BRASALADI (Brazil's Permanent Mission to ALADI/LAIA), to DMC/DIR/NALCAI/CGFOME, Brazilian Foreign Ministry, 1 December 2000, Arquivo do Ministério das Relaçǒes Exteriores (Archive of the Ministry of External Relations - AMER), Brasília, Brazil.

2 This analysis is possible and relevant given that Brazil is Mercosur's most important member state.

\section{References}

Battistella, Dario. 2003. Théories des Relations Internationales. Coll. Références inédites, éd. Presses de Sciences Po.

Cavlak Hakan, Abdülkadir Işik and Davuthan Günaydin. 2014. 'EU health policy: to what extent the EU got involved in the field of health?' In Engin Sorhun, Ümit Hacığlu and Hasan Dinçer (eds), Regional Economic Integration and the Global Financial System (Advances in Finance, Accounting, and Economics). IGI Global. pp. 98-109.

Cervo, Amado Luiz. 2008. Inserção Internacional - Formação dos Conceitos Brasileiros. São Paulo: Ed. Saraiva. Cervo, Amado Luiz and Clodoaldo Bueno. 2014. História da Política Exterior do Brasil. $5^{\text {th }}$ ed. Brasília: UnB.

Haas, Ernst B. 1958. The Uniting of Europe: Political, Social, and Economic Forces, 1950-1957. Stanford: Stanford University Press.

Hirst, Mônica and Miguel Lengyel. 1986. Las Relaciones Comerciais Argentino Brasilenas. Buenos Aires: Fiasco. 
Hoffmann, Stanley. 1964. 'The European process at Atlantic cross-purposes'. Journal of Common Market Studies 3 (1): 85-101.

Krishna-Hensel, Sai Felicia (ed). 2012. New Security Frontiers: Critical Energy and the Resource Challenge. Burlington: Ashgate.

Lindberg, Leon N and Stuart A Scheingold. 1970. Europe's Would-be Polity: Patterns of Change in the European Community. New Jersey: Prentice-Hall.

Mendes, Ricardo Gloe. 2001. 'Resolução de controvérsias no Mercosul: os interesses subnacionais'. Cadernos Cedec 69, Centro de Estudos de Cultura Contemporânea.

Moniz Bandeira, Luiz Alberto. 2001. 'Las relaciones en el Cono Sur: iniciativas de integración.' In Mario Rapoport and Amado Luiz Cervo (ed), El Cono Sur. Una historia común. Buenos Aires: Fondo de Cultura. pp. 281-322.

Moravcsik, Andrew. 1991. 'Negotiating the Single European Act: national interest and conventional statecraft in the European Community'. International Organization 45(1): 19-56.

. 1993. 'Preferences and power in the European Community: A liberal intergovernmentalist approach. Journal of Common Market Studies 31(4): 473-525.

. 1998. The Choice for Europe: Social Purpose and State Power from Messina to Maastricht. Ithaca: Cornell University Press.

Pentland, Charles. 1973. International Theory and European integration. London: Faber \& Faber.

Putnam, Robert D. 1998. 'Diplomacy and domestic politics: the logic of two-level games. International Organization 42 (3): 427-60.

Rosamond, Ben. 2000. Theories of European Integration. New York: Palgrave Macmillan.

\section{About the author}

Carlos Ricardo Caichiolo holds a PhD in Political and Social Sciences from the Université Catholique de Louvain (UCL), Belgium. He is Professor at the University Center of Brasília (UniCeub), Brazil, which he joined in 2002. Previously, he was Assistant Professor and Fellow of the Inter-American Studies Center linked to the Institute of High International Studies in Quebec, Canada. He has also been a Visiting Fellow of the Institute of International Politics and Economics in Belgrade, Serbia. He has also served as an advisor to the Department of International Relations and External Debt of the Central Bank of Brazil, mostly about Mercosur and the Free Trade Area of the Americas (FTAA). He is the author of Judicial Institutionalization of Integration Processes: Intergovernmentalism and Politicization in Mercosur.

Received on 6 June 2016, and approved for publication on 29 November 2016.

(cc) BY-NC https://creativecommons.org/licenses/by-nc/4.0/ 